\begin{tabular}{l|c|l}
\hline \hline Biological and & Vol. 5(2): 260-272, 2021 & $\begin{array}{l}\text { ISSN: 2002-6153 } \\
\text { Biol. Appl. Environ. Res. } \\
\text { www.baerj.com } \\
\text { editor@a baerj.com }\end{array}$ \\
\hline
\end{tabular}

\title{
Impact of Salinity Changes in Shatt Al-Arab Estuary on Biodiversity of Marine Mammals of the Arabian Gulf: A Review
}

\author{
Nader A. Salman ${ }^{*}$ \& Majid M. Taher ${ }^{2}$ \\ ${ }^{1}$ Al-Manara College for Medical Sciences, Maysan, Iraq \\ ${ }^{2}$ Aquaculture Unit, College of Agriculture, University of Basrah, Basrah, Iraq \\ *Corresponding author: naderabed@uomanara.edu.iq
}

\begin{abstract}
Salinity changes in the Shatt Al-Arab Estuary and North-West Arabian Gulf were monitored and reviewed in terms of the shortage of freshwater inflows to the Shatt Al-Arab Estuary. Data from previous and current surveys on marine mammals in the area have also been checked and compared to study the biodiversity under newly-developed circumstances. The Eco-physiological investigation was performed to assess the salinity tolerance limits of whales, dolphins and dugong. One-third of the world's 81 species of whales and dolphins, collectively called cetaceans, are thought to occur off the shores in the area. The new checklist is prepared according to recent surveys in the neighbouring Arab Gulf countries and the known checklist of mammals in Iraqi waters. Spatial variation of the marine mammals of the southern part was governed by the occurrence of feeding habitats rather than a direct response to salinity variations. Alteration of seaweed's habitats in response to water pollution is reported to have a direct effect on the biodiversity of mammals in the gulf. The results of this review were discussed in terms of salinity tolerance, hazardous ecological factors and spatial variation. No obvious effect of salinity changes imposed by the shortage of freshwater inflow on the distribution or loss of marine mammals neither on their habitat in the Arabian Gulf.
\end{abstract}

Keywords: Arabian Gulf, Marine mammals, Shatt Al-Arab Estuary

\section{Introduction}

The Arabian Gulf is a remarkably salty sea. There are few rivers to contribute a flow of freshwater, such as Shatt Al-Arab River which in turn suffer from freshwater flow. The Shatt Al-Arab River is the chief supply of fresh water to the northern Gulf. This river has a length of $195 \mathrm{~km}$ and an average width of $500 \mathrm{~m}$ with a depth that differs from 8-15 m downstream to Basrah (Al-Ramadhan \& Pastour, 1987). The usual river overflow into the gulf ranges from $1456 \mathrm{~m}^{3} / \mathrm{s}$ (Reynolds, 1993) to $1750 \mathrm{~m}^{3} / \mathrm{s}$ (Al-Hassan, 1999). Because of high temperatures, the shallow water evaporates faster than it is replaced by the inflow from the Tigris and Euphrates rivers and the smaller rivers of the eastern shore. Thus, though the salinity of the world's oceans averages 35\% psu, in the gulf the study of AlYamani et al. (2008) found salinities ranging from 38 to $70 \%$ psu in open waters. 
The high salt content of the water, like high temperatures, is a stress that gulf creatures, such as fishes and mammals, must be able to tolerate if they are to survive; many have learned to thrive on it, though through very effective osmoregulatory and thermal adaptability mechanisms (Al-Yamani et al., 2008).

Exceptionally high salinity embayment is common in many locations along the southern shores of the gulf. The relative richness and productivity of these areas are poorly understood; salinity rises to between 55 and $65 \%$, yet benthic diversity remains moderately high (Loughland \& Zainal, 2009), but where salinity rises to over $60-90 \%$, algae ultimately grade to cyanophyte dominated zones, with diminishing diversity. In extremes of these gradients, fauna becomes very limited though very few species may remain abundant (Al-Saad \& Salman, 2012).

However, relatively stable, high-level salinity and temperature environments in the Arabian Gulf are in contrast with the changing conditions of the monsoon regime and vigorous upwelling phenomena which govern the climate and productivity of the oceanic waters adjacent to the Arabian seas (Notarbartolo di Sciara et al., 2021). Despite the harsh environmental conditions of the Arabian Gulf, it contains internationally important ecosystems comprising coral reefs, seagrass beds and mangrove forests (Burt, 2014; Vaughan et al., 2019). The tropical waters of the Arabian Gulf have a long history of maritime resource richness and the high levels of biodiversity were due to the complex matrix of coastal habitats, coral reefs and seagrass beds in this region (Edmonds et al., 2021).

The freshwater inlets dilute the high salinity water of the north-western region of the gulf. The estuary represents a strong connection between the habitats of the inland marshes of Iraq and the northern part of the Arabian Gulf as far as the species and nutrients are concerned (Al-Yamani et al., 2008). There are several physical and chemical changes that the water discharge of the Shatt Al-Arab River generates in the northern part of the Arabian Gulf area (Jawad, 2021). These changes can be seen in the hydrodynamic variations, where the water discharge aids the counterclockwise circulation of the gulf; changes in both temperature and salinity (Al-Yamani et al., 2004; Al-Yamani, 2008). The most important is the drainage and the decrease in river water discharge due to upstream use. The shallow water in the northern part is influenced by the Shatt Al-Arab River discharge that is more productive than open gulf water (Nezlin et al., 2007).

Reduced flushing of Iraqi southern marshlands with freshwater decreased them from $8500 \mathrm{~km}^{2}$ in 1984 to $745 \mathrm{~km}^{2}$ in 2002. Flushing would aid in removing salts. Flooding the marshlands with river waters after the 2003 war partially restored them to $4000 \mathrm{~km}^{2}$ (Richardson et al., 2005; Jones et al., 2006).

Fluvial outflow is rich in nutrients (Talling, 1980) which can be attributed to the river run-off. These nutrients, silicates, in particular, sustain a qualitatively and quantitatively rich diatom crop in the northern gulf water (Subba Rao \& AlYamani, 2000).

Diversion of water increased pollution, and negatively impacted the biota. It reduces catches of commercially important fishes (Volovik, 1994). Changes in 
nutrient load, caused by damming, can affect the food web in surface waters (Humborg et al., 1997), which is possibly occurred in the gulf.

\section{Sources and Methods}

A total of 56 references (29 published research papers, nine reports, 12 books, three atlases and three classification and database websites) dealing with the ecology of the Arabian Gulf and Shatt Al-Arab Estuary concerning the biodiversity of the marine mammals in the Arabian Gulf were employed. Data from such references were gathered to provide reliable information on the impact of fluctuations of Shatt Al-Arab discharge on the environmental conditions of the Arabian Gulf and their effects on the occurrence of marine mammals. The review ended up by preparing a checklist of marine mammals recorded to occur in the Arabian Gulf. The scientific names, authorities and the classification families and orders in the checklist were prepared according to the Global Biodiversity Information Facility (GBIF, 2021). Scientific names of the marine mammals in the text were reported as they appeared in their original references.

\section{Results and Discussion \\ Mammals of the Arabian Gulf Cetaceans}

The Arabian Gulf is an important habitat for marine mammals. One-third of the 81 species of whales and dolphins, collectively called cetaceans, are thought to occur off the shores in the Arabian Gulf. According to some surveys, 21 species of cetaceans are reported to occur in the Arabian Gulf (Baldwin, 2003; Preen, 2004). About eleven species of dolphins and porpoises have been identified in the Arabian Gulf, most of which are very rarely encountered and suggested to be seasonal or transit visitors (EHC, 2003). The dolphins are better known than the whales, because some species are often encountered by fishermen and people in sailboats or yachts.

Much of what we know about the local species of cetaceans was based initially on proper research which was done by Robert Baldwin in the UAE. The aerial surveys of the southern and western Arabian Gulf (the waters of the UAE, Qatar, Bahrain and Saudi Arabia) that were conducted in 1986 and 1999/2000 provided a good picture of the relative abundance and distribution of small cetaceans (Preen, 2004). According to Preen (2004), during the aerial surveys, animals were counted along parallel strips of water (transects) that were $400 \mathrm{~m}$ wide and $3.7 \mathrm{~km}$ apart, so that $11 \%$ of the area was censused. In 1986, 65 groups of cetacean were counted and the index of abundance was 1,690 dolphins and porpoises. In 1999, only 19 groups were seen along the same transects and the index of abundance was only 489. The difference between surveys is statistically highly significant and indicates a $71 \%$ decline in the abundance of cetaceans over 13 years. 


\section{Near-shore Cetaceans}

Data from aerial surveys indicated that at least within nearshore waters (out to a depth of $>20 \mathrm{~m}$ ), the bottlenose dolphin Tursiops truncatus is the most common species, accounting for about $70 \%$ of all small cetaceans. The species was also mentioned to occur in the Arabian Gulf by Mohamed \& Hussain (1998), but no details were offered by those authors to distinguish the animals they sighted from T. aduncus. Notarbartolo di Sciara et al. (2021) suggested that more data must be collected before T. truncatus is considered to be present in the gulf. Instead, $T$. aduncus seemed to be recorded throughout the region's coastal waters (Braulik et al., 2010; Cowan, 2013). The bottlenose dolphin is less restricted and occurs in shallow through to deep water. Only $29 \%$ of bottlenose dolphins seen on the aerial surveys were in water less than $10 \mathrm{~m}$ deep (Preen, 2004). It is easily recognized by its short stubby beak and a large forehead.

The humpback dolphin Sousa chinensis is most common in shallower waters and is the species most likely to be seen very close to the coast. During the aerial surveys, $96 \%$ of humpback dolphins were in water less than $10 \mathrm{~m}$ deep. The IndoPacific humpback dolphin makes up about 27\%. It stays in shallow but open waters. According to Bishop \& Alsaffar (2008) between February 2004 through 1 March 2005, 524 Sousa chinensis dolphins were observed over a total of 389 hours. Observations were recorded for each water body surrounding Boubyan Island. Seasonal sightings of $S$. chinensis peaked in spring at nearly $2 / \mathrm{h}$. Overall, April was the best month for $S$. chinensis sightings at nearly $4 / \mathrm{h}$, and Khor Abdullah, with an average of $2 / \mathrm{h}$, was the best location. The highest monthly sightings of $S$. chinensis occurred in Khor Abdullah in June when an average of 6.5/h was observed. Based on the maximum number of sightings in one day, the population of S. chinensis in the Boubyan area is believed to be 70-100 individuals. Another humpback dolphin, S. plumbea, is an exclusively coastal species that is frequently reported from very shallow nearshore waters with a largely continuous distribution along much of the coastline of the Arabian Gulf (Baldwin et al., 2004; Notarbartolo di Sciara et al., 2021).

The Indo-Pacific finless porpoise is recorded in the gulf throughout coastal waters from the Strait of Hormuz, Iran, Kuwait, Saudi Arabia, Qatar, Bahrain and UAE (Baldwin, 2003; Collins et al., 2005). In the habitat of shallow water channels between mudbanks and mangrove swamps lining the offshore islands, the rare finless porpoise (Neophocaena phocaenoides) is most at ease (Bishop \& Alsaffar, 2008). The finless porpoise is the smallest dolphins, distinguished by the lack of a dorsal fin. This dolphin likes to come close inshore to hunt in the mangrove-lined shallow sea-water channels of the offshore islands. It counts for 1-2\% of the total. The few sightings of finless porpoise suggest that it may be found in shallow or deep water (Bishop \& Alsaffar, 2008). An even more acrobatically gifted dolphin is the Spinner dolphin (Stenella lonirostris). It is smaller (up to $2 \mathrm{~m}$ ) and has a white belly and a grey flank band. During its leaps, it spins around its longitudinal axis and somersaults in spectacular displays. Spinners can occur both in the deep waters of the Arabian Gulf in pods of up to 300 individuals. 


\section{Deep Water Cetaceans}

The deep waters of the Arabian Gulf on the edge of the continental shelf contain more species than the warm, sandy shallow waters. In the former habitat, one may find the mighty sperm whale (Physeter macrocephalus) that reaches 20 meters in length, although no confirmed records of sperm whales in the gulf (Notarbartolo di Sciara et al., 2021). Even larger blue whale (Balaenoptera musculus) which may grow to 30 meters in length could be found here as reported by Baldwin (2003) who suggested that blue whales are rare, but widespread in the region, occurring even in the Arabian Gulf. The largest of the dolphins, the 4 meters long Risso's dolphin (Grampus griseus), a deep water species, which was not confirmed to be recorded from the gulf because the basin is not expected to be a suitable habitat for them (Notarbartolo di Sciara et al., 2021).

The other baleen whale is the fin whale (Balaenoptera physalus) that grows up to 20 meters in length. It is both an open ocean dweller and a visitor of coastal waters and therefore found in the Arabian Gulf. Among the smaller whales are Bryde's whale (Balaenoptera edeni), the Sei whale (Balaenoptera borealis) and the mink whale (Balaenoptera acutorostrata). Bryde's whale has been recorded from the Arabian Gulf as mentioned by Braulik et al. (2010) and Notarbartolo di Sciara et al. (2021) who stated that this species occurs regularly in the gulf. It is probably the most common whale on the coast and breeds in this region. The Sei whale grows up to 20 meters long and is easily confused with other whales of similar size. They are, however, rarely seen since they stay in deep waters.

All the other odontocetes here are dolphins, including the misnamed killer whales and false killer whales. Killer whales (Orcinus orca) appear to occur with some regularity in the gulf (Baldwin et al., 1999). They live and hunt in pods of up to 30 individuals. The false killer whale (Pseudorca crassidens) has been recorded from the Arabian Gulf (Preen, 2004). It is widely distributed throughout the Arabian region, including the Arabian Gulf (Al-Robbae, 1971; Baldwin, 2003). They can approach within touching distance and are a favourite of whale-spotters. Owfi et al. (2016) stated that the most recorded dolphins were finless porpoise, Indo-pacific humpback dolphin and Indo-pacific bottlenose dolphin, and this is reflecting their inshore distribution and local abundance.

\section{Sirenians (Dugongs)}

The Arabian Gulf is home to the largest known population of dugongs (Dugong dugon). The highest numbers are found in the gulf off the coasts of Saudi Arabia, Bahrain, Qatar and UAE (Preen, 2004). They appear to be only occasional visitors to the north Arabian Gulf coast. Abu Dhabi Emirate contains about half the gulf population of dugongs and represents the single most important site for this threatened species in the western half of its world range (EHC, 2003).

The dugong is an unusual marine mammal of tropical and subtropical coastal waters of the Indian and southwest Pacific oceans. Dugongs feed almost exclusively on seagrasses, making them the only herbivorous mammal that is strictly marine. They are long-lived, slow-breeding animals. They become sexually 
mature between 10-15 years of age, have a single calf every 3-7 years and can live to the age of 70 years (Marsh et al., 1984). Dugongs are docile, relatively slowmoving, large, and, in many countries, a desirable source of meat. Moreover, their seagrass diet restricts them to the same shallow coastal waters that are most intensively used by people. Seagrasses loss can adversely affect the occurrence and distribution of the species.

\section{Osmoregulatory Adaptation to Salinity Changes}

Ecophysiological adaptations of cetaceans in response to salinity changes are concentrated on preventing the uptake of more saltwater. This will enable marine mammals to live without an urgent need for freshwater. Such osmoregulatory adaptation can be done through various mechanisms, such as preventing the penetration of water by the impermeable skin, satisfying water requirements via their fish food which contains more diluted fluids than seawater, inactivation of water reabsorption process by the kidney and conserving metabolic water by underskin fatty layers in a similar manner to that of desert animals (Salman \& Eddy, 1988).

\section{Threats of Marine Mammals in the Arabian Gulf Cetaceans}

Many marine world megafauna's populations have decreased due to unsustainable direct exploitation or incidental mortality (Anderson et al., 2011; McClellan et al., 2014). Many coastal cetaceans have distinct 'home ranges' restricting their ability to simply move to alternative habitats nearby (Baldwin et al., 1999; Baldwin, 2003), and alternatives are, in any case, often greatly altered themselves. A range of insidious threats such as pollution and noise occur in the gulf, some of which are difficult to quantify (Reynolds et al., 1999). Few cetaceans have been studied in the gulf in any detail (Baldwin, 2003), some exceptions being the 'very rare' finless porpoise (Reeves et al., 1997; Jefferson \& Hung, 2004). The status of $S$. chinensis is unknown (Baldwin et al., 2004), except for records at Kuwait's Boubyan Island (Bishop \& Alsaffar, 2008). A single published set of cetacean abundance measurements in UAE waters, however, provides evidence for a marked decline in dolphins. During an aerial census focusing on dugongs in 1986 and repeated in 1999, Preen (2004) detected a statistically significant decline of over $70 \%$ in dolphin abundance.

All of the whales and many of the dolphins are endangered animals. Threats to whales are widespread and include fishery entanglements (Moazzam \& Nawaz, 2014), ship strikes and pollution (Dakhteh et al., 2017). Owfi et al. (2016) stated that the largest threat to marine mammals in Iran is incidental capture in fishing gears, where six bycaught finless porpoises were recorded and it is well known that this species may be particularly vulnerable to incidental mortality caused by gillnets.

The decline in cetacean numbers is a matter of great concern. Factors contributing to this decline are likely to be repeated cetacean die-offs and mortality 
in fishing nets. Dolphins and porpoises may get caught in the large-meshed nets. There have been at least two substantial die-offs of small cetaceans in the Arabian Gulf since the 1986 survey. In late 1986, at least 532, and perhaps up to 2,000 cetaceans died along the coasts of Qatar, Saudi Arabia and Bahrain. Most of the dead dolphins were found near the southern Qatar border, suggesting that the dieoff extended into the UAE. In 1991, 81 cetacean carcasses were found along the Saudi and Bahrain coasts (Preen, 2004) and this die-off may also have extended into the UAE. These die-offs could have had a serious impact on the populations of cetaceans in the UAE. Small cetaceans are known to be vulnerable to drowning in fishing nets (Harwood \& Hembree, 1987) and at least two species are in imminent danger of extinction because of net-fishing activities (Perrin et al., 1994).

There is little current information on the status of the Bryde's whales in the region, although evidence from relatively frequent stranding's suggests they are vulnerable to entanglement in gillnets and ship strikes (Kershaw et al., 2013). There is no information on the current status of the Blue whale in the region, though infrequent live sightings and strandings confirm their continued occurrence (Notarbartolo di Sciara et al., 2021). Evidence for human-caused mortality of Sperm whale, including those caused by ship-strike, fisheries interactions and sound pollution from oil exploration activities have been described from an assessment of a limited number of strandings (Baldwin, 2003). The Indo-Pacific common dolphin is frequently recorded as bycatch (Braulik et al., 2010). There was a mass stranding of 11 Indo-Pacific common dolphins at Bandar-e-Jask on the Iranian coast, in 2011 (Mohsenian et al., 2014).

\section{Dugongs}

The fate of dugongs is increasingly dependent upon the actions of humans. Internationally, dugongs are listed as vulnerable to extinction (IUCN, 1996), and they are listed as endangered in many jurisdictions. Although dugongs are legally protected in many countries, there is generally little enforcement of these laws and dugongs are still widely hunted and caught in nets. Due to their low reproductive rate, dugong populations are likely to decline if human-related mortality exceeds 1$2 \%$ of females per year (Marsh et al., 1984). However, hunting has declined in the Arabian region, due to the increased affluence of coastal people (Preen, 1989). In most areas, the take of dugongs in mesh fishing nets now seems to be a greater threat. These nets, which may be set primarily to catch fishes or dugongs, are now extremely widespread in subsistence and commercial fisheries in tropical coastal waters. Dugongs are known to get caught in the large-meshed nets used in the Marawwah Island region of Abu Dhabi.

Over the period 1986 and 1999, the dugong population remained unchanged despite documented chronic impacts from fisheries activities, such as bycatch (Baldwin \& Cockcroft, 1997). The global status of D. dugon was assessed as vulnerable on the IUCN Red List. However, assessments conducted on a regional basis recognized that dugongs from the Arabian Gulf still be considered as data deficient (Marsh et al., 2011). 
Dugongs are also vulnerable to pollution, especially by oil. In the Arabian Gulf, at least 37 (but possibly more than 200) dugongs died during the 1983 Nowruz oil spill (Preen, 1989). Loss of habitat also threatens dugongs in some areas. Seagrass meadows that support dugongs can be damaged or lost as a result of increased water turbidity, sedimentation, eutrophication or disease (den Hartog, 1987; Walker $\&$ McComb, 1992). Dugong populations that are fragmented and reduced by overexploitation become especially vulnerable to rare events like oil spills or natural disasters.

\section{Globally Threatened Marine Mammals}

Globally threatened marine species, used to be present in the Arabian Gulf, are blue whale, Balaenoptera musculus (absent from Northern Gulf), humpback whale, Megaptera novaeangliae (absent from Northern Gulf) and dugong, Dugong dugon (vagrant in Northern Gulf, important further south).

Finally, it's appropriate to show here a list of marine mammals of the Arabian Gulf. The following is a systematic account of such mammals. Their scientific names, authorities, families and orders are according to GBIF (2021).

Phylum Chordata

Class Mammalia

Order Cetacea

Family Balaenopteridae

Balaenoptera acutorostrata Lacépède, 1840

Balaenoptera edeni Anderson, 1879

Balaenoptera borealis Lesson, 1828

Balaenoptera musculus (Linnaeus, 1758)

Balaenoptera physalus (Linnaeus, 1758)

Megaptera novaeangliae (Borowski, 1781)

Family Delphinidae

Delphinus delphis Linnaeus, 1758

Grampus griseus (G. Cuvier, 1812)

Orcinus orca (Linnaeus, 1758)

Pseudorca crassidens (Owen, 1846)

Sousa chinensis (Osbeck, 1765)

Sousa plumbea (G. Cuvier, 1829)

Stenella longirostris (Gray, 1828)

Tursiops aduncus (Ehrenberg, 1833)

Tursiops truncatus (Montagu, 1821)

Family Phocoenidae

Neophocaena phocaenoides (G. Cuvier, 1829)

Family Physeteridae

Physeter macrocephalus Linnaeus, 1758 
Order Sirenia

Family Dugongidae

Dugong dugon (Müller, 1776)

\section{Conclusions}

As a conclusion, we can summarize the following general threats of marine mammals in the Arabian Gulf: Fishing or accidentally fishing by seine and trawling nets, destroying the mammal's habitats, pollutions, especially oil pollution, disturbance due to aquaculture and tourism, epidemic diseases and accidents of collision with marine boats.

\section{References}

Al-Hassan, L.A.J. (1999). Shad of the Shatt Al-Arab River in Iraq. Shad J. 4(2): 14.

Al-Ramadhan, B.M. \& Pastour, M. (1987). Tidal characteristics of Shatt AlArab River. Mar. Mesopot., 2(1): 15-28.

Al-Robbae, K. (1971). False killer whale Pseudorca crassidens, a new record for the Arab Gulf. Bull. Iraqi Nat. Hist. Mus., 5(1): 31-34.

Al-Saad, H.T. \& Salman, N.A. (2012). Status of oil pollution in the Arabian Gulf and Shatt Al-Arab Estuary: A review. In: Subramanian, V. (ed.) Coastal environments: Focus on Asian regions. Springer, Dordrecht: 3646. DOI:10.1007/978-90-481-3002-3_3.

Al-Yamani, F. (2008). Importance of the freshwater influx from the Shatt al-Arab River on the Gulf marine environment. In: Abuzinada, A.H.; Barth, H.-J.; Krupp, F.; Böer, B. \& Al-Abdessalaam, T.Z. (eds.). Protecting the gulf's marine ecosystems from pollution. Birkhäuser, Basel: 207-222. DOI:10.1007/ 978-3-7643-7947-6_11.

Al-Yamani, F.Y.; Bishop, J.M.; Ramadhan, E.; Al-Husaini, M. \& Al-Ghadban, A. (2004). Oceanographic atlas of Kuwait's waters. Kuwait Inst. Sci. Res., Kuwait: 202 pp.

Al-Yamani, F.; Polikarpov, I.; Skryabin, V.; Bishop, J.; Al-Rifaie, K.; AlMansouri, H.; Al-Enezi, M.; Lennox, A.; Al-Kandari, M.; Behbehani, M.; AlGhunaim, A. \& Ismail, W. (2008). Assessment of the effects of the Shatt AlArab's altered discharge regimes on the ecology of the Northern Arabian Gulf- Phase II. KISR, Final Report, 9061: 744 pp.

Anderson, O.R.J.; Small, C.J.; Croxall, J.P.; Dunn, E.K.; Sullivan, B.J.; Yates, O. \& Black, A. (2011). Global seabird bycatch in longline fisheries. Endangered Species Res., 14(2): 91-106. DOI:10.3354/esr00347.

Baldwin, R.M. (2003). Whales and dolphin of Arabia. Mazoon Printing Press, Muscat, Sultanate of Oman: $111 \mathrm{pp}$.

Baldwin, R.M. \& Cockcroft, V.G. (1997). Are dugongs, Dugong dugon, in the Arabian Gulf safe? Aquat. Mamm., 23(2): 73-74.

Baldwin, R.M.; Van Waerebeek, K. \& Gallagher, M. (1999). A review of cetaceans from waters off the Arabian Peninsula. In: Fisher, M.; Ghazanfar, S.A. \& 
Spalton, J.A. (eds.). The natural history of Oman: A festschrift for Michael Gallagher. Backhuys Publ., Leiden: 161-189.

Baldwin, R.M.; Collins, T.; Van Waerebeek, K. \& Minton, G. (2004). The IndoPacific humpback dolphin of the Arabian region: A status review. Aquat. Mamm., 30(1): 111-124. DOI:10.1578/AM.30.1.2004.111.

Bishop, J.M. \& Alsaffar, A.H. (2008). Quantitative observations on marine mammals and reptiles of Kuwait's Boubyan Island. Zool. Mid. East, 43(1): 312. DOI:10.1080/09397140.2008.10638263.

Braulik. G.T.; Ranjbar, S.; Owfi, F.; Aminrad, T.; Dakhteh, S.M.H.; Kamrani, E. \& Mohsenizadeh, F. (2010). Marine mammal records from Iran. J. Cetacean Res. Manag., 11(1): 49-63.

Burt, J.A. (2014). The environmental costs of coastal urbanization in the Arabian Gulf. City, 18(6): 760-770. DOI:10.1080/13604813.2014.962889.

Collins, T.; Preen, A.; Willson, A.; Braulik, G. \& Baldwin, R.M. (2005). Finless porpoise (Neophocaena phocaenoides) in waters of Arabia, Iran and Pakistan. Document SC/57/SM6 presented to the IWC Sci. Comm., Ulsan, Korea: 20 pp.

Cowan, P.J. (2013). An annotated checklist of the mammals of Kuwait. Sultan Qaboos Univ. J. Sci., 18: 19-24.

Dakhteh, S.M.H.; Ranjbar, S.; Moazeni, M.; Mohsenian, N.; Delshab, H.; Moshiri, H.; Nabavi, S.M.B. \& Van Waerebeek, K. (2017). The Persian Gulf is part of the habitual range of the Arabian Sea humpback whale population. J. Mar. Biol. Oceanogr., 6(3): 1-6. DOI:10.4172/2324-8661.1000178.

den Hartog, C. (1987). "Wasting disease" and other dynamic phenomena in Zostera beds. Aquat. Bot., 27(1): 3-14. DOI:10.1016/0304-3770(87)90082-9.

Edmonds, N.J.; Al-Zaidan, A.S.; Al-Sabah, A.A.; Le Quesne, W.J.F.; Devlin, M.J.;

Davison, P.I. \& Lyons, B.P. (2021). Kuwait's marine biodiversity: Qualitative assessment of indicator habitats and species. Mar. Pollut. Bull., 163: 1-15. DOI:10.1016/j.marpolbul.2020111915.

EHC (Emirates Heritage Club) (2003). Marine Atlas of Abu Dhabi. Centro Poligrafico Milano S.P.A. - Casarile, Milano: 277 pp.

GBIF (2021). Global Biodiversity Information Facility, on-line database, http://www.gbif.org. (Accessed 9 April 2021).

Harwood, M.B. \& Hembree, D. (1987). Incidental catch of small cetaceans in the offshore gillnet fishery in Northern Australian waters: 1981-1985. Rep. Int. Whal. Commn., 37: 363-367.

Humborg, C.; Ittekkot, V.; Cociasu, A. \& Bodungen, B.V. (1997). Effect of Danube River dam on Black Sea biogeochemistry and ecosystem structure. Nature, 386: 385-388. DOI:10.1038/386385A0.

IUCN (1996). IUCN Red List of Threatened Animals. Compiled by Baillie, J. \& Goombridge, B. I.U.C.N. Species Survival Commission, Gland, Switzerland \& Oxford: 488 pp. https://portals.iucn.org/library/BC-RL-1996-001.

Jawad, L.A. (2021). A proposal for creating a directory of marine biota gauges in Iraq. In: Jawad, L.A. (ed.). The Arabian Seas: Biodiversity, environmental 
challenges and conservation measures: 691-700. Springer Nature, Switzerland AG. DOI:10.1007/978-3-030-51506-5_28.

Jefferson, T.A. \& Hung, S.K. (2004). Neophocaena phocaenoides. Mammalian Species, 746: 1-12. In: Jen, E. (ed.). A repertoire of biological, ecological, and engineering case studies. Oxford Univ. Press: $318 \mathrm{pp}$.

Jones, C.K.; Sultan, M.; Yan, E.; Al-Dousari, A.; Al-Kaisy, S.; Becker, R. \& Milewski, A. (2006). An integrated approach (RS, GIS, \& modeling) for the assessment of the disintegration and renovation of the Mesopotamian Marshlands. AGU Joint Assembly, Baltimore USA, May 2006, American Geophysical Union: 23-26.

Kershaw, F.; Leslie, M.S.; Collins, T.; Mansur, R.M.; Smith, B.D.; Minton, G.; Baldwin, R.; LeDuc, R.G.; Anderson, R.C.; Brownell, R.L. \& Rosenbaum, H.C. (2013). Population differentiation of 2 forms of Bryde's whales in the Indian and Pacific oceans. J. Hered., 104(6): 755-764. DOI:10.1093/ jhered/est057.

Loughland, R.A. \& Zainal, A.J.M. (eds.) (2009). Marine atlas of Bahrain. GEOMATEC, Bahrain Centre for Studies and Research, Manama: 384 pp.

Marsh, H.; Heinsohn, G.E. \& Marsh, L.M. (1984). Breeding cycle, life history and population dynamics of the dugong, Dugong dugon (Sirenia: Dugongidae). Aust. J. Zool., 32(6): 767-788. DOI:10.1071/Z09840767.

Marsh, H.; O'Shea, T.J. \& Reynolds, J.E. (2011). Ecology and conservation of the Sirenia: Dugongs and manatees. Cambridge Univ. Press, Cambridge: 521 pp. McClellan, C.M.; Brereton, T.; Dell'Amico, F.; Johns, D.G.; Cucknell, A.-C. \& Patrick, S.C. (2014). Understanding the distribution of marine megafauna in the English Channel region: Identifying key habitats for conservation within the busiest seaway on earth. PLoS ONE 9(2): e89720. DOI:10.1371/ journal.pone.0089720.

Moazzam, M. \& Nawaz, R. (2014). By-catch of tuna gillnet fisheries of Pakistan: A serious threat to non-target, endangered and threatened species. J. Mar. Biol. Ass. India, 56(1): 85-90. DOI:10.6024/jmbai.2014.56.1.01750s-13.

Mohamed, A.R.M. \& Hussain, N.A. (1998). Observations on the occurrence of the bottlenose dolphins Tursiops truncatus in Iraqi waters. Mar. Mesopot., 13(2): 409-415.

Mohsenian, N.; Moshiri, H.; Sedighi, O.S.K.; Norbakhsh, S.; Heidary, S.; Shamili, K.S. \& Braulik, G.T. (2014). The first long-beaked common dolphin mass stranding in Iranian waters. Mar. Biodivers. Rec., 7: e64. DOI:10.1017/ S1755267214000669.

Nezlin, N.P.; Polikarpov, I.G. \& Al-Yamani, F. (2007). Satellite-measured chlorophyll distribution in the Arabian Gulf: Spatial, seasonal and interannual variability. Int. J. Oceans Oceanogr., 2(1): 139-156. http://www.ripublication.com/ ijoo.htm.

Notarbartolo di Sciara, G.; Baldwin, R.; Braulik, G.; Collins, T. \& Natoli, A. (2021). Marine mammals of the Arabian seas. In: Jawad, L.A. (ed.). The Arabian seas: Biodiversity, environmental challenges and conservation 
measures. Springer Nature Switzerland AG: 637-678. DOI:10.1007/978-3030-51506-5_26.

Owfi, F.; Braulik, G.T. \& Rabbaniha, M. (2016). Species diversity and distribution pattern of marine mammals of the Persian Gulf and Gulf of Oman- Iranian Waters. Iran. J. Fish. Sci., 15(2): 927-944.

Perrin, W.F.; Caldwell, D.K. \& Caldwell, M.C. (1994). Atlantic spotted dolphin Stenella frontalis (G. Cuvier, 1829): 173-190. In: Ridgway, S.H. \& Harrison, R. (eds.). Handbook of marine mammals, Volume 5: Academic Press, San Diego: $418 \mathrm{pp}$.

Preen, A. (1989). The status and conservation of dugongs in the Arabian region. Saudi Arabia, Coastal and Marine Management Series (MEPA), Report No. 10, Vol, 1: xix + $200 \mathrm{pp}$.

Preen, A. (2004). Distribution, abundance and conservation status of dugongs and dolphins in the southern and western Arabian Gulf. Biol. Conserv., 118(2): 205-218. DOI:10.1016/j.biocon.2003.08.014.

Reeves, R.R.; Wang, J.W. \& Leatherwood, S. (1997). The finless porpoise, Neophocaena phocaenoides (G. Cuvier, 1829): A summary of current knowledge and recommendations for conservation action. Asian Mar. Biol., 14: 111-143.

Reynolds, R.M. (1993). Physical oceanography of the Persian Gulf, Strait of Hormuz, and the Gulf of Oman: Results from the Mt. Mitchell expedition. Mar. Pollut. Bull., 27: 35-59.

Reynolds, J.E., III, Odell, D.K. \& Rommel, S.A. (eds.) (1999). Marine mammals of the World: 1-4. In: Reynolds, J.E., III \& Rommel, S.A. Biology of marine mammals, Smithsonian Institution Press, Washington, DC: 578 pp.

Richardson, C.J.; Reiss, P.; Hussain, N.A.; Alwash, A.J. \& Pool, D.J. (2005). The restoration potential of the Mesopotamian marshes of Iraq. Science, 307(Issue 5713): 1307-1311. DOI:10.1126/science.1105750.

Salman, N.A. \& Eddy, F.B. (1988). Kidney function in response to salt feeding in rainbow trout (Salmo gairdneri Richardson). Comp. Biochem. Physiol., 89A(4): 535-539.

Subba Rao, D.V. \& Al-Yamani, F. (2000). The Arabian Gulf. In: Sheppard, C. (ed.), Seas at the Millennium: An environmental evaluation. Elsevier Science Ltd., Chapter 53: 1-16.

Talling, J.F. (1980). Water characteristics. In: Rzoska, J. (ed.), Euphrates and Tigris: Mesopotamian ecology and destiny. Monographiae Bilogicae, Springer, Dordrecht, 38: 63-86. DOI:10.1007/978-94-009-9171-2_6.

Vaughan, G.O.; Al-Mansoori, N. \& Burt, J.A. (2019). The Arabian Gulf. In: Sheppard, C. World seas: An environmental evaluation ( $2^{\text {nd }}$ edition). Elsevier: 1-23. DOI:10.1016/B978-0-08-100853-9.00001-4.

Volovik, S.P. (1994). The effects of environmental changes caused by human activities on the biological communities of the River Don (Azov Sea Basin). Water Sci. Technol., 29(3): 43-47. DOI:10.2166/wst.1994.0059. 
Walker, D.I. \& McComb, A.J. (1992). Seagrass degradation in Australian coastal waters. Mar. Poll. Bull., 25(5-8): 191-195. DOI:10.1016/0025326X(92)90224-T. 